\title{
Nest sites selection by sympatric cavity-nesting birds in miombo woodlands
}

\begin{tabular}{|c|c|}
\hline $\begin{array}{l}\text { Authors: } \\
\text { Vincent R. Ny } \\
\text { Felistus C. Che } \\
\text { Exildah Chish } \\
\text { Peter A. Linds }\end{array}$ & $\begin{array}{l}\text { renda }{ }^{1} \\
\text { we }^{2} \\
- \text { Kasumu }^{3} \\
y^{4}\end{array}$ \\
\hline $\begin{array}{l}\text { Affiliations: } \\
{ }^{1} \text { Department } \\
\text { Aquatic Scien } \\
\text { Copperbelt Ur }\end{array}$ & $\begin{array}{l}\text { f Zoology and } \\
\text { es, The } \\
\text { iversity, Zambia }\end{array}$ \\
\hline $\begin{array}{l}{ }^{2} \text { Department } \\
\text { Kansanshi Co } \\
\text { Zambia }\end{array}$ & $\begin{array}{l}\text { f Environment, } \\
\text { per Mine, }\end{array}$ \\
\hline $\begin{array}{l}{ }^{3} \text { Department } \\
\text { Environmenta } \\
\text { Copperbelt Ur }\end{array}$ & $\begin{array}{l}\text { f Plant and } \\
\text { Sciences, The } \\
\text { iversity, Zambia }\end{array}$ \\
\hline $\begin{array}{l}{ }^{4} \text { Department } \\
\text { Entomology, } \\
\text { Pretoria, Sout }\end{array}$ & $\begin{array}{l}\text { foology and } \\
\text { niversity of } \\
\text { Africa }\end{array}$ \\
\hline $\begin{array}{l}\text { Correspondin } \\
\text { Vincent Nyire } \\
\text { vrnyirenda@h }\end{array}$ & $\begin{array}{l}\text { author: } \\
\text { da, } \\
\text { otmail.com }\end{array}$ \\
\hline $\begin{array}{l}\text { Dates: } \\
\text { Received: } 10 \\
\text { Accepted: } 06 \\
\text { Published: } 26\end{array}$ & $\begin{array}{l}\text { ept. } 2015 \\
\text { ppr. } 2016 \\
\text { July } 2016\end{array}$ \\
\hline $\begin{array}{l}\text { How to cite th } \\
\text { Nyirenda, V.R. } \\
\text { Chisha-Kasum } \\
\text { P.A., 2016, 'Ne } \\
\text { selection by s } \\
\text { cavity-nesting } \\
\text { miombo woo } \\
\text { 58(1), a1359. } \\
\text { org/10.4102/ } \\
\text { v58i1.1359 }\end{array}$ & $\begin{array}{l}\text { is article: } \\
\text { Chewe, F.C., } \\
\text { u, E. \& Lindsey, } \\
\text { st sites } \\
\text { mpatric } \\
\text { birds in } \\
\text { lands', Koedoe } \\
\text { ttp://dx.doi. } \\
\text { oedoe. }\end{array}$ \\
\hline $\begin{array}{l}\text { Copyright: } \\
\text { (C) 2016. The A } \\
\text { Licensee: AOS } \\
\text { is licensed unc } \\
\text { Creative Comr } \\
\text { Attribution Lic }\end{array}$ & $\begin{array}{l}\text { uthors. } \\
\text { S. This work } \\
\text { ler the } \\
\text { nons } \\
\text { ense. }\end{array}$ \\
\hline Read online: & \\
\hline 口ista & $\begin{array}{l}\text { Scan this QR } \\
\text { code with your } \\
\text { smart phone or } \\
\text { mobile device } \\
\text { to read online. }\end{array}$ \\
\hline
\end{tabular}

Deforestation and habitat fragmentation have long been known as drivers of wildlife depletion but information on their specific impacts on cavity-nesting birds in the miombo woodlands has been lacking. A comparative study of disturbed and undisturbed sites was conducted in miombo woodlands of Zambia to assess impacts of environmental stressors on birds. Foot patrols were employed to locate, identify and count host trees and cavities for cavity-nesting birds on twenty $200 \mathrm{~m} \times 200 \mathrm{~m}$ sample plots. Undisturbed forests had three times more cavities (the nesting sites for birds), while there were $24.6 \%$ fewer abandoned cavities in undisturbed forests than in disturbed forests. The rate of cavity abandonment was about twice as high in human-dominated forests compared to undisturbed forests (61.3\% c.f. $31.9 \%$ ). Cavity-nesting birds preferred larger (> $36.0 \mathrm{~cm}$ diameter at breast height) and taller $(>5.0 \mathrm{~m}$ ) trees for nest placement, especially in human-dominated forests. A number of cavity-nesting birds preferred Brachystegia spiciformis (zebrawood), Julbernadia paniculata (munsa), Parinari curatellifolia (mobola-plum) and Uapaca kirkiana (mahobohobo) as host trees to 14 other miombo tree species. Arnot's Chat (Myrmecocichla arnoti) had a wider selection of host trees for cavity-nesting than the other 40 cavity-nesting birds in the study areas. Anthropogenic activities such as uncontrolled firewood collection, wild fires, logging, and land clearing for agriculture negatively influenced wood abundance and diversity, with potential implications for persistence of cavity-nesting birds. The negative impacts of anthropogenic activities could be counteracted by conservation strategies such as implementation of sound forest policies, integrative land use practices, sustainable livelihood security and stakeholders' awareness of the need to safeguard forest-dependent avifauna.

Conservation implications: This comparative study unravels specific anthropogenic impacts on the cavity-nesting birds in the miombo woodlands, which would be relevant for designing and implementing targeted biodiversity conservation interventions against negative local environmental values and attitudes that support rural development on the expense of conservation of biodiversity such as birds.

\section{Introduction}

Cavity-nesting birds use hollow spaces as nesting sites. Nest site selection by cavity-nesting birds is influenced by multiple factors such as habitat conditions, life-history traits and tree preferences of cavity-nesting birds (Politi \& Hunter 2009). Most cavity-nesting birds prefer sizeable trees of $>30 \mathrm{~cm}$ in diameter at breast height (DBH) (Lehmkuhl et al. 2003), though younger trees may have suitable cavities depending on the species of the tree and on factors such as the frequency and intensity of fires and disease (Gibbons et al. 2002). Cavity abundance is influenced by the species of tree, $\mathrm{DBH}$, position on the trunk, and whether the tree is alive or dead (Carlson, Sandström \& Olsson 1998). Wood that is susceptible to insects and fungi due to low resin levels in the wood is more conducive to cavity formation (Shigo \& Marx 1977). Other tree-dependent characteristics for cavity formation include the porosity, texture of the wood, and exposure to light (Saab, Dudley \& Thompson 2004). Cavitynesting birds select nests based on the depth of the cavity (Belthoff \& Ritchison 1990), the body size of bird species (Carlson et al. 1998) and the orientation of the entrance (Radford \& Du Plessis 2003).

The structural condition of both dead and living trees determines the extent and nature of cavity development. The presence of dead wood or broken treetops promote development of cavities by cavity-nesting birds, though with reduced permanence compared to living trees 
especially in trees with high compartmentalisation (a process of isolating fungal affected sapwood tissue) which facilitates sapwood growth (Lehmkuhl et al. 2003). Firescarred woods are prone to higher cavity holding rates than wood that is not exposed to fires, because fire induces weakness that makes it easy for excavators (Hunter \& Mazurek 2003). Sometimes fires are followed by termite and fungal attacks in cracked and scarred portions of trees (Jackson \& Jackson 2004). Therefore, cavity formation is greatly affected by the frequency and intensity of fires. In addition to fire-scarring of forested areas, the cavity-nest densities and nest survival for cavity-nesting birds are influenced by the periods since fires occurred and wood logging (Saab, Russell \& Dudley 2007). Further, foraging excavators may also serve as vectors by depositing fungal spores or hyphae at the tree cracks, which eventually develop into fungal conks (Farris, Huss \& Zack 2004).

Predation is another form of disturbance that influences nest site selection by cavity-nesting birds (Wesolowski 2002). Nest predation commonly involves depredation of eggs or chicks by reptilian and mammalian tree-climbers, and birds of prey (Wilson et al. 1998). The suitability of potential nest sites is also based on the prospects offered of avoiding predation and maximisation of reproductive success for cavity-nesting birds. The choice of nest sites by cavity-nesting birds is often influenced by factors such as the height above the ground, vegetal concealment of entrances of cavities, and neighbouring vegetation type due to edge effects (Fisher \& Wiebe 2005). Site-choice may be further influenced by competition. Inter-specific competition for cavities involves multiple species of cavity-nesting birds and other taxa such as various mammal species (Kappes \& Davis 2008). Mammals, birds, amphibians, reptiles, and insects can compete for cavities to fulfil various behavioural needs such as resting, roosting, breeding, feeding, and hiding (Gibbons et al. 2002). In cases of intense inter-specific competition, resource partitioning is a common strategic response by the species involved (Harrington et al. 2009). An example of such resource partitioning is in the use of different sized cavities by species of different sizes. Relatively small sized cavities form realised niches for small cavity-nesting birds by excluding larger nest users. In addition, cavity-nesting birds employ exclusionary strategy of territorialism (Wesolowski 1989). For instance, Starlings (Sturnus vulgaris) are known to constrain Tree Swallows (Tachycineta bicolour) to smaller nest sizes and remote nest sites from woodlands (Dobkin et al. 1995). In another example, woodhoopoes defend their core territorial areas where suitable cavities for roosting and breeding are found from competitor species (Du Plessis 1992; Du Plessis, Simmons \& Radford 2007). Some cavity-nesting birds shift their nesting behaviour seasonally due to aggressive competition from other species (Koenig 2003). Further, anthropogenic disturbances are among key drivers of nest choice and abandonment rates of cavities by birds, especially during breeding season (Richardson \& Miller 1997). Removal of wood by humans negatively reduces the availability and diversity of cavities for birds (Du Plessis 1995). Cavitynesters also frequently experience intra-specific competition, either due to low supply of cavities for nest sites or due to competition for vantage points (Czeszczewik \& Walankiewicz 2003).

Miombo woodlands are rich in cavities, albeit there is a lack of information on the conservation status of cavitynesting birds or on availability of nest sites in the miombo woodlands. The miombo woodlands are dry tropical deciduous forests growing in central and southern parts of Africa (Schwartz, Caro \& Banda-Sakala 2002), covering $\sim 10 \%$ of the continent (Millington et al. 1994). Miombo woodlands comprise mostly the family Fabaceae and the genera Brachystegia, Julbernardia and Isoberlinia (Dewees et al. 2011; Ryan, Williams \& Grace 2010). Various tree species are found in a miombo biome including Brachystegia spiciformis (zebrawood), Julbernardia paniculata (munsa), Julbernardia globiflora (mnondo), Parinari curatellifolia (mobola-plum), Syzygium guineense (waterberry), Uapaca species (mahobohobo) and Isoberlinia angolensis (kapane). A characteristic of miombo woodlands is that the constituent trees grow to great heights and girths (Frost 1996), providing significant resources for humans and wildlife. For humans, miombo woodlands provide highly valued timber, non-timber forest products such as fruits, edible caterpillars and mushrooms, while for wildlife of various taxa, miombo woodlands provide food and habitats (Kalaba, Quinn \& Dougill 2013).

Miombo woodlands are inhabited by a wide range of species of cavity-nesting birds such as woodpeckers, barbets, owls, hornbills, woodhoopoes, rollers, kingfishers and starlings (Dowsett, Aspinwall \& Dowsett-Lemaire 2008; Hockey, Dean \& Ryan 2005; Leonard 2005). The cavity-nesting birds seek wood crevices to use as nesting places, landmarks for their territories, provision of insects as source of food to those that are also insectivores, and protection from the direct sunlight and precipitation (Ober \& Minogue 2007). However, miombo woodlands are under acute threat from expanding human activities such as deforestation that results from timber harvesting, charcoal production, uncontrolled human-induced wild fires, and clearance of vegetation for agriculture, settlement and industry (Turner II, Lambin \& Reenberg 2007). Unlike natural factors such as droughts, and wild fires from lightening which are stochastic in nature, anthropogenic factors causing deforestation are usually deterministic and often result in environmental degradation. Zambia for example, suffers some of the fastest rates of deforestation in the world, losing an estimated total area of forests of between $2500 \mathrm{~km}^{2}$ per year and $3000 \mathrm{~km}^{2}$ per year (Ministry of Tourism, Environment and Natural Resources; United Nation's Food and Agricultural Organisation 2008). 
Despite extensive studies globally on the ecology of cavitynesting birds (e.g. Cockle, Martin \& Wesolowski 2011; Kemp 2000; Rhodes, O’Donnell \& Jamieson 2009), empirical evidence of impacts of anthropogenic activities on cavitynesting birds in the miombo woodlands has been lacking. Miombo woodland transformation results in multi-scale landscape dynamics in what are social-ecological systems, leading to various structural and process responses (Zurlini et al. 2013). Structural responses relate to changes in species composition and diversity while process responses relate to evolutionary and ecological functional elements of woodlands. Shifts such as land use transformations would likely require landscape-based interventions for biodiversity conservation (Benayas \& Bullock 2012; Jones et al. 2010). Natural ecosystems can assimilate some disturbance, while at the same time maintaining ecological processes through resilience (Carpenter \& Brock 2008; Walker \& Salt 2006). Birds act as bio-indicators of ecosystem performance in increasingly human-modified systems (Holt \& Miller 2011; Mayer, Donovan \& Pawlowski 2014).

We assessed the impacts of human activities such as uncontrolled firewood collection, logging, fires, and land clearing for commercial purposes on cavity-nesting birds. Key research questions included the assessment of: (1) to what extent do human-induced disturbances affect wood abundance and diversity? (2) How do wood abundance and diversity influence nest site selection by sympatric cavitynesting birds in the miombo woodlands?

\section{Methods}

\section{Study sites}

We used two study sites: the human-dominated Mwekera National Forests No. 6 in Kitwe, and the undisturbed forests of Chimfushi Wildlife Orphanage in Chingola, both in the Copperbelt province of Zambia (Figure 1) (hereafter referred to as Mwekera and Chimfushi). Miombo woodlands cover $\sim 45 \%$ of Zambia's landmass (Stringer et al. 2012) and in both study areas, the vegetation is predominantly miombo, characterised by vegetation types in Table 3. In the case of Mwekera, there are also exotic Eucalyptus globulus (blue gum), Eucalyptus tereticornis (forest red gum), Pinus kesiya (khasi), Pinus oorcarpa (ocote chino) and Pinus merkusii (merkus) plantations.

\section{Mwekera}

The average human population density in the Copperbelt province is 63.0 persons per $\mathrm{km}^{2}$, with an average annual rate of population growth of 2.2\% (Central Statistical Office 2012). Mwekera $\left(\sim 111 \mathrm{~km}^{2}\right)$ lies at an elevation of $1245 \mathrm{~m}$ a.s.1 $1310 \mathrm{~m}$ a.s.l., with an annual average ambient temperature of $19.7{ }^{\circ} \mathrm{C}$, and mean annual rainfall of $1300 \mathrm{~mm}$. The area forests were established as a National Forest to protect the Mwekera stream catchment, which is part of the Kafue River system. However, the Mwekera forests have been undergoing rapid degradation mainly due to unauthorised settlements (Zimba 2007). Historical research suggests that the Mwekera

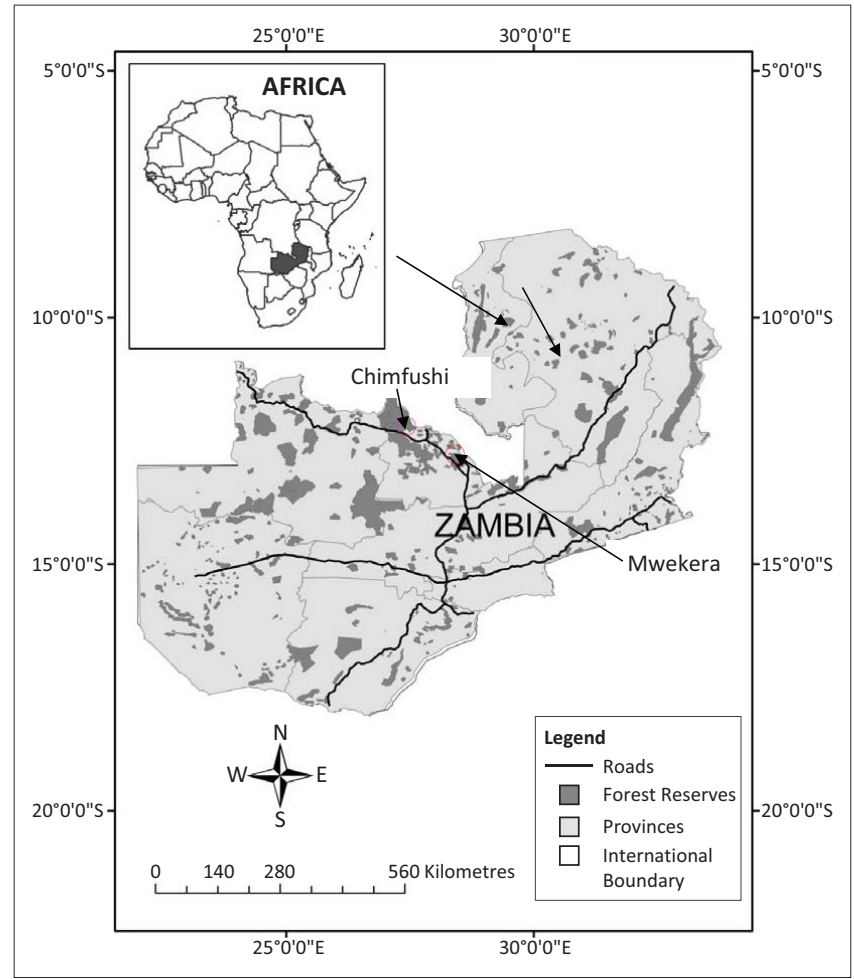

FIGURE 1: Locations of Mwekera National Forests No. 6 and Chimfushi Wildlife Orphanage forests in Zambia.

forests supported a higher diversity of birds, mammals and reptiles in the past than what persist today (Dowsett et al. 2008; Leonard 2005). For instance, mammals such as elephants (Loxodonta africana), lions (Panthera leo), leopards (Panthera pardus), eland (Taurotragus oryx), sable (Hippotragus niger) and impala (Aepyceros melampus), in addition to several bird species, have been extirpated in the last three decades due to human-induced disturbances (P.M. Fushike, pers. comm., 05 December 2014). However, various species of small-bodied species of wildlife such as rodents, lizards and squirrels persist.

\section{Chimfushi}

Chimfushi is a private farm $\left(\sim 93 \mathrm{~km}^{2}\right)$ on the banks of the Kafue River, in Chingola District, Copperbelt Province of Zambia (Figure 1). Management of the property excludes human intrusions into the area. Chimfunshi occurs at an altitude of $1280 \mathrm{~m}$ above sea level and has mean annual temperature and precipitation of $20.7{ }^{\circ} \mathrm{C}$ and $1200 \mathrm{~mm}$ respectively. The area is used primarily as a sanctuary for orphaned chimpanzees (Pan troglodytes) but is also populated with blue monkeys (Cercopithecus mitis), sitatungas (Tragelaphus spekii), hippos (Hippopotamus amphibius) and Nile crocodiles (Crocodylus niloticus) in addition to a variety of other mammals, birds, reptiles and amphibians.

\section{Data collection protocols}

We conducted bird surveys at the two sites during August and September 2014 for owls and in November-February 2014/2015 for the rest of the cavity-nesting birds. These 
periods coincided with the time when most of the tree cavity-nesting birds such as southern ground hornbills, barbets, hornbills, and woodpeckers have their breeding seasons (Hockey et al. 2005). Observations were conducted during 09:00-11:00 hrs when birds were typically active. Data was collected from ten randomly selected sampling plots of quadrats that measured $200 \mathrm{~m} \times 200 \mathrm{~m}$ in size, and were located at least $500 \mathrm{~m}$ away from vegetation ecotones. The plots were visited and inspected once every fortnight during the survey period. Although the number of bird species was not enumerated in this study, data on species presence and absence were recorded. Two observers searched each plot for tree cavities and dead wood. The use of cavities by birds was ascertained by remote observations of bird nesting, feeding, and social behaviour around the nesting sites (Dowsett et al. 2008; Leonard 2005; Newman \& Read 2008). By using this indirect method, we did not need to reach and inspect physical features such as remnants of eggshells, feathers and droppings in the nests, thereby minimising disturbances to the cavity-nesting birds. Therefore, consistent bird activity in the form of nesting, feeding and roosting at the nest sites during the breadth of study period (or lack thereof) was taken as being indicative of whether the respective nests were still active or abandoned. Placement of nests was indirectly measured from tree $\mathrm{DBH}$ approximately $1.3 \mathrm{~m}$ above the ground to determine the tree size preferences by cavity-nesting birds and angular measurements for estimation of tree heights were made by use of Suunto hypsometer clinometers, following standard methods described by Avery and Burkhart (1994) and Leverett (2010). Hundred-metre measuring steel tape and rope were also used for estimation of distances. Enumerated trees were marked and tagged with metal plates for ease of subsequent identification. Differences in tree diameters over study period were not obtained on assumption that in-season variations resulting from contraction and expansion of trees were insignificant during the relatively short peak season for the breeding cavity-nesting birds as suggested by Krauss et al. (2007) and O'Brien et al. (2008). Dried and rotting wood was considered dead; wood in a posture perpendicular to flat ground (with about zero slope) was taken as standing wood, while wood prostrating on the ground was considered 'lying' wood. Tasco binoculars, with magnification of 20x, were used to aid in identifying cavity-nesting birds. Guide books were used for taxonomic classification of plants and birds (Leonard 2005; Newman \& Read 2008).

\section{Analyses}

Minitab (2004), (Minitab Inc., Pennsylvania, USA), version 14 statistical software was used in the statistical analyses. Twosample $T$-test was used to establish whether the quantum of trees and active cavities significantly varied or not between the two study sites, using the procedure stipulated by Fowler, Cohen and Jarvis (2006). Relative plant species abundance was analysed for comparative commonness or rarity in the two study sites (McGill et al. 2007). Since diversity is non- linear, beta diversity which compares elements of diversity such as different vegetation communities was adopted. Thus, we derived comparable estimates of the effective number of tree cavities for bird nesting from exponentials of ShannonWeaver indices (Jost 2006; Magurran 2004). From conservation perspective, Shannon-Weaver index is used to measure and compare components of conservation status between different sites with similar environments (Fowler et al. 2006). It is represented by $H^{\prime}=-\Sigma P_{i}\left(\ln P_{i}\right)$, where $H^{\prime}$ is diversity index, $P_{i}$ is the proportion of each component in the sample and $\ln P_{i}=$ natural logarithm of this proportion. The higher the $H^{\prime}$ value, the greater the diversity. Use of indices is important and common in biodiversity monitoring due to the difficult in elucidating absolute enumeration of biodiversity (Barry et al. 2013; Tuomisto 2012). In the case of bird abundance, presence or absence data were analysed for each cavity-nesting bird.

\section{Results \\ Species presence and absence}

There were 41 cavity-nesting bird species at the two study sites (Table 1). Cavity-nesting birds with the highest number of species were owls (seven species), woodpeckers (six species) and kingfishers (six species) and the birds with the lowest number of species were chats and parrots (Table 1 ). Out of the 41 bird species in the study sites, only $12.2 \%$ $(n=5)$ occurred in human-dominated forests (Table 1).

\section{Wood, cavities and cavity-nesting birds interrelationships}

The undisturbed and disturbed forests had mean tree densities of $3.2 \pm 0.02$ trees per ha (range: $2-5$ trees per ha) and $1.8 \pm 0.05$ trees per ha (range: $1-2$ trees per ha) respectively. Mean tree densities in undisturbed forests were significantly higher than in disturbed forests ( $T$-test $=5.52 ; d f=9 ; P<0.001$ ). The mean abundance of active cavities was higher in the undisturbed site relative to disturbed sites at $17.4 \pm 2.4$ (range: $11-26)$ and $4.0 \pm 1.1$ (range: $1-7)(T$-test $=12.79 ; d f=9$; $P<0.001$, Table 2). The number of tree cavities in undisturbed forests was $139.6 \%$ greater than in disturbed forests out of the 360 tree cavities that were recorded in the study area. Similarly, the number of tree cavities with active bird presence was $321.9 \%$ greater in the undisturbed forests than disturbed forests. The remainder of the 146 cavities in the study area were abandoned by the cavity-nesting birds. There were $24.6 \%$ fewer abandoned cavities in undisturbed than in disturbed forests (Table 2). The rate of cavity abandonment was about twice as high in human-dominated forests compared to undisturbed forests (61.3\% c.f. $31.9 \%$ ) (Tables 2 and 3).

Undisturbed forests had 71.9\% more dead wood than humandominated forests, as recorded from a total of 14 tree species and 201 dead wood (Table 2). More than two thirds of dead wood with cavities was found in undisturbed forests. There were $44.8 \%$ more wood without cavities in human-dominated forests relative to undisturbed forests. 
TABLE 1: Presence and absence of key cavity-nesting birds in Mwekera National Forests No. 6 and the Chimfushi Wildlife Orphanage forests, Copperbelt Province, Zambia, 2014.

\begin{tabular}{|c|c|c|c|c|c|}
\hline \multirow[t]{2}{*}{ Bird species } & \multirow[t]{2}{*}{ Scientific names } & \multicolumn{2}{|c|}{$\begin{array}{c}\text { Mwekera } \\
\text { (human-dominated forests) }\end{array}$} & \multicolumn{2}{|c|}{$\begin{array}{c}\text { Chimfushi } \\
\text { (undisturbed forests) }\end{array}$} \\
\hline & & Presence & Absence & Presence & Absence \\
\hline Wood Owl & Strix woodfordii & $x$ & - & - & $x$ \\
\hline Barn Owl & Tyto alba & - & $x$ & $x$ & - \\
\hline African Scops Owl & Otus senegalensis & $\mathrm{x}$ & - & $x$ & - \\
\hline White-faced Scops Owl & Otus leucotis & - & $x$ & $x$ & - \\
\hline Spotted Eagle Owl & Bubo africanus & - & $x$ & $x$ & - \\
\hline Giant Eagle Owl & Bubo lacteus & - & $x$ & $x$ & - \\
\hline Barred Owlet & Glaucidium capensis & - & $x$ & $x$ & - \\
\hline Bearded Woodpecker & Thripias namaquus & - & $x$ & $x$ & - \\
\hline Olive Woodpecker & Mesopicos griseocephalus & - & $x$ & $x$ & - \\
\hline Cardinal Woodpecker & Dendropicos fuscescens & $x$ & - & $x$ & - \\
\hline Golden-tailed Woodpecker & Campethera abingoni & $x$ & - & $x$ & - \\
\hline Bennett's Woodpecker & Campethera bennetti & - & $x$ & $x$ & - \\
\hline Southern Ground Hornbill & Bucorvus cafer & - & $\mathrm{x}$ & $\mathrm{x}$ & - \\
\hline Crowned Hornbill & Tockus alboterminatus & - & $\mathrm{x}$ & $x$ & - \\
\hline Pale-billed Hornbill & Tockus pallidirostris & - & $\mathrm{x}$ & $x$ & - \\
\hline Trumpeter Hornbill & Bycanistes bucinator & - & $\mathrm{x}$ & $x$ & - \\
\hline Arnot's Chat & Myrmecocichla anorti & $\mathrm{x}$ & - & $x$ & - \\
\hline Mosque Swallow & Hirundo senegalensis & - & $\mathrm{x}$ & $x$ & - \\
\hline Red-breasted Swallow & Hirundo semirufa & - & $x$ & $x$ & - \\
\hline Lesser-striped Swallow & Hirundo abyssinica & - & $x$ & $x$ & - \\
\hline Greater-striped Swallow & Hirundo cucullata & - & $x$ & $x$ & - \\
\hline European Swallow & Hirundo rustica & - & $x$ & $x$ & - \\
\hline Meyer's Parrot & Poicephalus meyeri & - & $x$ & $x$ & - \\
\hline Half-collared Kingfisher & Alcedo semitorquata & - & $x$ & $x$ & - \\
\hline Malachite Kingfisher & Alcedo cristata & - & $x$ & $x$ & - \\
\hline Brown-headed Kingfisher & Halcyon albiventris & - & $x$ & $x$ & - \\
\hline Pied Kingfisher & Ceryle rudis & - & $x$ & $x$ & - \\
\hline European Roller & Coracias garrulus & - & $\mathrm{x}$ & $x$ & - \\
\hline Lilac-breasted Roller & Coracias caudatus & - & $x$ & $x$ & - \\
\hline Broad-billed Roller & Eurystomus glaucurus & - & $\mathrm{x}$ & $x$ & - \\
\hline Red-billed Wood hoopoe & Phoeniculus purpureus & - & $x$ & $x$ & - \\
\hline Hoopoe & Upupa epops & - & $\mathrm{x}$ & $x$ & - \\
\hline Whyte's Barbet & Stactolaema whytii & - & $x$ & $x$ & - \\
\hline Miombo pied Barbet & Tricholaema frontata & - & $x$ & $x$ & - \\
\hline Black-collared Barbet & Lybius torquatus & - & $x$ & $x$ & - \\
\hline Black-backed Barbet & Lybius minor & - & $x$ & $x$ & - \\
\hline Sharp-tailed Starling & Lamprotornis acuticaudus & - & $x$ & $x$ & - \\
\hline Violet-backed Starling & Cinnyricinclus leucogaster & - & $\mathrm{x}$ & $x$ & - \\
\hline
\end{tabular}

\section{Cavity-nesting birds' adaptation strategies}

Birds placed their cavity-nests at greater heights in humandominated forests than in undisturbed forests (Table 2). Out of the 201 recordings of dead wood, 81 were prostrate while 123 were standing: a greater proportion of standing wood was found in undisturbed forests (Table 2). Prostrate wood in human-dominated forests included those that were cut by humans and left to dry. Diameter at breast height for the trees used by cavity-nesting birds ranged from $31.2 \mathrm{~cm}$ to $39.2 \mathrm{~cm}$ while cavity-nest height ranged from $3.2 \mathrm{~m}$ to $5.7 \mathrm{~m}$ above the ground (Table 2). Although undisturbed forests had suitable trees (> $36.0 \mathrm{~cm}$ tree DBH and $>5.0 \mathrm{~m}$ high) for cavity-nesting birds, a substantial proportion of nests $(48.3 \%)$ were also placed in small trees $(<36.0 \mathrm{~cm} \mathrm{DBH}$ and $<5.0 \mathrm{~m}$ high $)$. In contrast, a small proportion of only $20 \%$ of the total cavitynests were placed $<5.0 \mathrm{~m}$ in trees of $<36.0 \mathrm{~cm} \mathrm{DBH}$ in human- dominated forests. In the entire study area, the cavity-nesting birds preferred large tall trees for nesting as depicted in Figures 2 and 3 . The effective number of active cavities was almost three times greater in undisturbed forests than in the human-dominated forests, indicating enhanced nesting sites in the former (Table 2).

The tree species richness was higher in undisturbed forests (inverse of Simpson's richness index $=12.6$ ) than in humandominated forests (inverse of Simpson's richness index $=10.0$ ). Further, cavity-nesting birds showed varied preferences for host trees (Tables 3 and 4). B. spiciformis, J. paniculata, P. curatellifolia and Uapaca kirkiana hosted a greater variety of cavity-nesting birds than other host trees. Arnot's Chats had a wider selection of host trees for cavitynesting than other cavity-nesting birds. 
TABLE 2: Parameters explaining occurrence of tree cavities in Mwekera National Forests No. 6 and the Chimfushi Wildlife Orphanage forests, Copperbelt Province, Zambia, 2014.

\begin{tabular}{|c|c|c|c|c|c|c|}
\hline \multirow[t]{2}{*}{ Parameter } & \multicolumn{3}{|c|}{$\begin{array}{c}\text { Mwekera } \\
\text { (human-dominated forests) }\end{array}$} & \multicolumn{3}{|c|}{$\begin{array}{c}\text { Chimfushi } \\
\text { (undisturbed forests) }\end{array}$} \\
\hline & Range per site & Mean \pm SE per site & Total in Mwekera & Range per site & Mean \pm SE per site & Total in Chimfushi \\
\hline Number of active cavities & $1-7$ & $4.0 \pm 1.1$ & 41 & $11-26$ & $17.4 \pm 2.4$ & 173 \\
\hline Number of abandoned cavities & $1-12$ & $6.6 \pm 2.1$ & 65 & $2-13$ & $8.0 \pm 1.9$ & 81 \\
\hline Number of dead wood with cavities & $2-5$ & $3.2 \pm 0.5$ & 32 & $6-14$ & $9.8 \pm 1.6$ & 98 \\
\hline Number of dead wood without cavities & $2-7$ & $4.2 \pm 1.0$ & 42 & $1-5$ & $3.0 \pm 0.7$ & 29 \\
\hline Number of standing wood & $1-5$ & $3.2 \pm 0.8$ & 33 & $6-11$ & $9.0 \pm 0.9$ & 90 \\
\hline Number of lying wood & $2-6$ & $4.2 \pm 0.7$ & 43 & $1-8$ & $3.8 \pm 1.2$ & 38 \\
\hline Mean DBH $(\mathrm{cm})$ & $31.2-35.9$ & $33.6 \pm 1.0$ & - & $33.2-39.2$ & $36.4 \pm 0.9$ & - \\
\hline Nest height (m) & $4.0-5.7$ & $5.2 \pm 0.3$ & - & $3.2-5.1$ & $4.6 \pm 0.4$ & - \\
\hline Effective number of active cavities $\dagger$ & - & - & 2.7 & - & - & 7.4 \\
\hline
\end{tabular}

$\dagger$, Effective number of active cavities for bird nesting indicated the comparable number of cavities where there was active presence of birds.

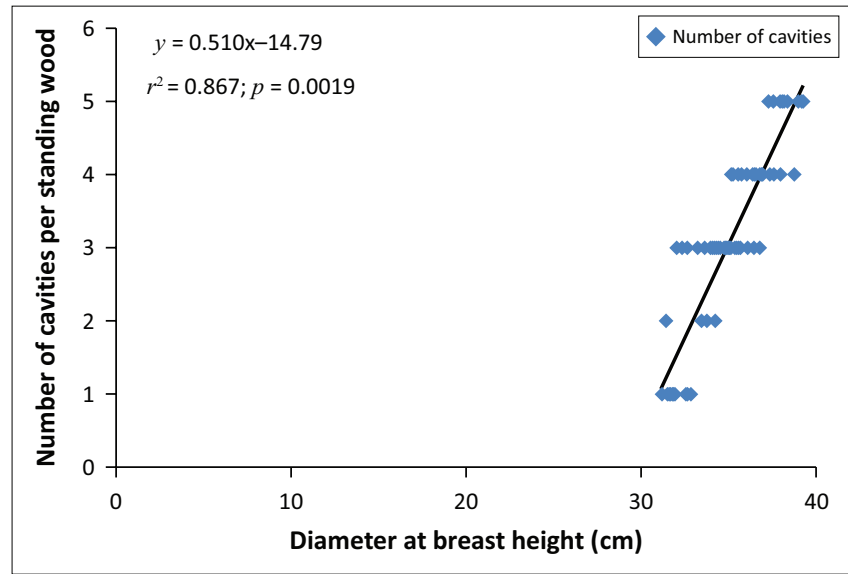

FIGURE 2: Correlates between number of cavities per standing wood and diameter at breast height in the study areas of Chimfushi and Mwekera forests, Zambia, in 2014.

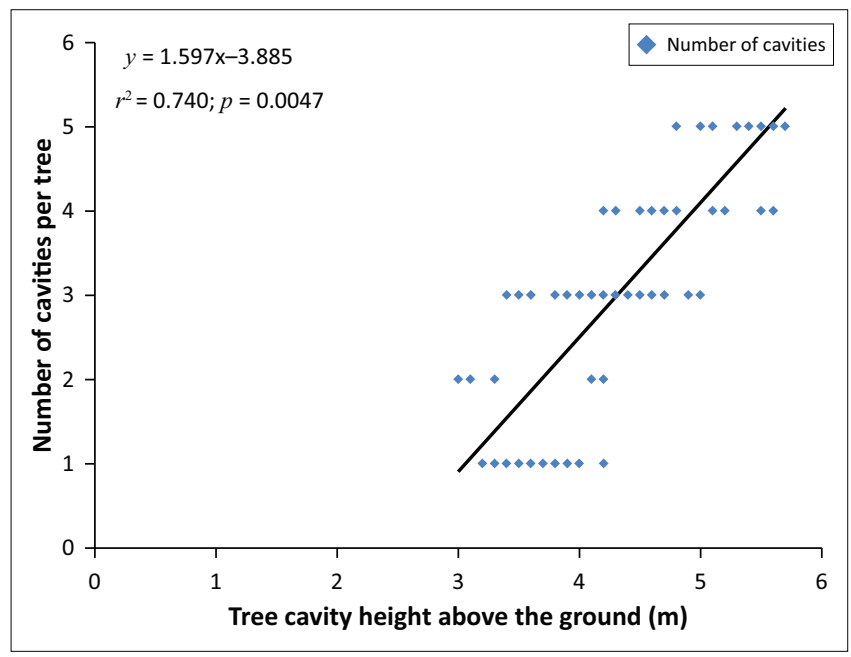

FIGURE 3: Correlates between number of cavities per standing wood and minimum tree height in the study areas of Chimfushi and Mwekera forests, Zambia, in 2014

\section{Discussion}

\section{Persistence of sympatric cavity-nesting birds}

In this study, undisturbed forests found in the Chimfushi area supported a more diverse array of cavity-nesting birds than human-dominated forests in Mwekera. In both forest types, environmental conditions were similar except for the direct anthropogenic factors such as uncontrolled firewood collection, logging, wild fires, and land clearing for agriculture purposes that occurred in the Mwekera forests. The aforementioned anthropogenic factors could have been responsible for the occurrence of much less abundance and diversity of cavity-nesting birds in the Mwekera forests than the Chimfushi forests. According to Trzcinski, Fahrig and Merriam (1999) and Roberts (2007), environmental factors such as deforestation and habitat fragmentation might trigger the presence or absence of certain cavity-nesting birds in a particular area. Based on studies conducted elsewhere, it would also appear that undisturbed forests contain more cavity-nesting birds than disturbed forests, due in part to increased availability of nesting sites (dos Anjos 2006; Reid et al. 2014). Some bird species in the study areas might have been affected by direct persecution by humans and other predators. For instance, owls are persecuted by local communities based on superstitions surrounding them (Lee \& Irwin 2005), despite owls being natural biological control agents of pests such as rodents and insects in agrarian and semi-urban landscapes (Meyer 2008).

In both study areas, the most prevalent cavity-nesting birds were the African Scops Owl and the Wood Owl and these birds had successfully adapted thus far to the humandominated landscapes. There is the likelihood that both the African Scops Owl and Wood Owl species persist on the abundant rodents and insects found in human-dominated landscapes (Carrete et al. 2010; Dowsett et al. 2008). However, the quantity and diversity of bird species any forest can support depend on the capacity of the vegetation to absorb disturbance (Carpenter \& Brock 2008; Folke et al. 2010). Cavity-nesting bird populations are largely resident and non-migratory in nature (Reid et al. 2014; Wilson \& Hockey 2013). On the other hand, secondary cavity-nesting birds such as southern ground hornbills, Arnot's Chats, and White-faced Scops Owls are likely to be more negatively impacted by the absence of the host vegetation than primary cavity-nesting birds that create their own tree cavities, without having to adopt or re-use the existing cavities. The dependence on existing cavities by secondary cavity-nesting birds speculates why secondary cavity-nesting birds have difficulties to survive forest disturbance trajectories such as forest succession and transformations (Martin \& Eadie 1999). 
TABLE 3: Tree species and their associated nesting cavities in the 20 sample plots in Mwekera National Forests No. 6 and the Chimfushi Wildlife Orphanage forests, Copperbelt Province, Zambia, 2014.

\begin{tabular}{|c|c|c|c|c|c|c|c|c|}
\hline \multirow[t]{2}{*}{ Tree species } & \multicolumn{4}{|c|}{$\begin{array}{c}\text { Mwekera } \\
\text { (human-dominated forests) }\end{array}$} & \multicolumn{4}{|c|}{$\begin{array}{c}\text { Chimfushi } \\
\text { (undisturbed forests) }\end{array}$} \\
\hline & $\begin{array}{l}\text { Quantity } \\
\text { (number) }\end{array}$ & $\begin{array}{l}\text { Proportion } \\
\quad(\%)\end{array}$ & $\begin{array}{l}\text { Active cavities } \\
\text { (number) }\end{array}$ & $\begin{array}{l}\text { Abandoned } \\
\text { cavities (number) }\end{array}$ & $\begin{array}{l}\text { Quantity } \\
\text { (number) }\end{array}$ & $\begin{array}{l}\text { Proportion } \\
\quad(\%)\end{array}$ & $\begin{array}{l}\text { Active cavities } \\
\text { (number) }\end{array}$ & $\begin{array}{c}\text { Abandoned } \\
\text { cavities (number) }\end{array}$ \\
\hline Parinari curatellifolia & 11 & 15.7 & 10 & 1 & 14 & 10.6 & 37 & 3 \\
\hline Brachystegia boehmii & 10 & 14.3 & 5 & 36 & 11 & 9.1 & 4 & 5 \\
\hline Lannea discolour & 4 & 5.7 & 0 & 2 & 19 & 13.6 & 9 & 12 \\
\hline Brachystegia spiciformis & 10 & 14.3 & 2 & 9 & 10 & 7.6 & 6 & 2 \\
\hline Vitex doniana & 4 & 5.7 & 0 & 0 & 13 & 9.1 & 68 & 2 \\
\hline Albizia anthunesia & 7 & 10.0 & 0 & 0 & 8 & 6.1 & 4 & 3 \\
\hline Pterocarpus angolensis & 4 & 5.7 & 7 & 0 & 11 & 7.6 & 8 & 13 \\
\hline Uapaca kirkiana & 3 & 4.3 & 0 & 10 & 10 & 7.6 & 7 & 22 \\
\hline Anisophyllea boehmii & 4 & 5.7 & 13 & 0 & 7 & 6.1 & 19 & 7 \\
\hline Isoberlinia angolensis & 4 & 5.7 & 0 & 7 & 9 & 6.1 & 0 & 4 \\
\hline Diplorhynchus condylocarpon & 1 & 1.4 & 0 & 0 & 5 & 4.6 & 7 & 1 \\
\hline Hymonecardia acidia & 0 & 0 & 0 & 0 & 2 & 1.5 & 1 & 0 \\
\hline Total & 70 & 100 & 41 & 65 & 132 & 100 & 173 & 81 \\
\hline
\end{tabular}

In addition, cavity dwelling bird species such as Bearded Woodpecker (Thripias namaquus), Olive Woodpecker (Mesopicos griseocephalus), Cardinal Woodpecker (Dendropicos fuscescens) and Golden-tailed Woodpecker (Campethera abingoni) implement various survival strategies against predation risks, including predator avoidance and narrowing sizes of entrance holes (Kemp 2001; Reed 2001). According to Sinclair, Fryxell and Caughley (2006), the ability for birds to adapt to environmental changes through use of rare resources by generalist foraging and nesting behaviour in a range of habitat conditions may contribute to the persistence of particular avifauna.

\section{Wood abundance and its influence on nesting cavities}

The quantity of suitable wood for nesting cavities is typically a limiting factor for populations of cavity-nesting birds (Laudenslayer 2002; Newton 1998). Adverse anthropogenic activities such as land clearing for agriculture, logging, uncontrolled fires and firewood collection can reduce the number of cavities below a critical threshold for the persistence of cavity-nesting birds. Human-induced and uncontrolled bush fires in the miombo woodlands are common, especially in Zambia where implementation of forestry policies and laws are relaxed (Eriksen 2007). However, factors such as the abundance of live or dead, rotten or solid, broken or intact wood, and also the presence or absence of certain wood types are particularly important in determining the persistence of cavity-nesting birds.

\section{Adaptation of cavity-nesting birds to human disturbances}

In this study, $81.3 \%$ of active nests were found placed high on large-diameter trees (Figures 2 and 3). The selection of largediameter trees in human-dominated forests indicated that there was a preference by birds to use of large-diameter nest trees over small ones. The reason cavity-nesting birds preferred large-diameter trees could have been that birds enjoyed protection from predation, competition and some human disturbances, maximised nest space and thermal insulation (Laudenslayer 2002). For instance, nests placed in high cavities suffer lower predation rates and enjoy higher success for persistence (Joy 2010). In this regard, birds counteract environmental adversity by adapting their behaviour.

Our analysis buttresses the theory of 'realised ecological niche' - a nesting site where birds would actually thrive amidst adversaries (Sinclair et al. 2006). However, while there are still some species that have adapted to numerous disturbances in the Mwekera forests, dead wood which provides preferred resources for cavity-nesting birds are more prone to fires and collection for human use than fresh standing trees, especially in unmanaged forests (Stephens 2004). In addition, due to anthropogenic disturbance, juvenile and coppicing trees are often not allowed to grow older to provide decaying portions for creation of cavities. The sourcing of firewood is also selective because local communities target certain tree species, in particular those with hard wood which often provide ideal habitats for cavitynesting birds.

\section{Conservation implications}

Avian species conservation in changing environments demands that there should be monitoring, integrated land management and concerted effort (Nelson 2008). Thus, physical and cognitive aspects of conservation need to be addressed to ensure persistence of cavity-nesting birds. Physical aspects of such interventions include implementation of policies, forest management plans and best practices. Cognitive aspects of the appropriate interventions include integrating supportive perceptions and attitudes in resource users. For instance, stakeholders' awareness of ecological processes and the structure of miombo woodlands associated with bird conservation are critical in the light of many forest 
TABLE 4: Cavity-nesting birds and their preferred host tree species in Mwekera National Forests No. 6 and the Chimfushi Wildlife Orphanage forests, Copperbelt Province, Zambia, 2014.

\begin{tabular}{|c|c|c|c|c|c|c|c|c|c|c|c|c|c|c|}
\hline \multirow[t]{2}{*}{ Cavity-nesting birds } & \multicolumn{14}{|c|}{ Tree species } \\
\hline & 1 & 2 & 3 & 4 & 5 & 6 & 7 & 8 & 9 & 10 & 11 & 12 & 13 & 14 \\
\hline Wood Owl & - & - & - & $M$ & - & - & - & - & - & - & - & - & - & - \\
\hline Barn Owl & - & - & - & $C$ & - & - & - & - & - & - & - & - & - & - \\
\hline African Scops Owl & - & - & - & - & M & - & - & - & - & - & - & - & - & - \\
\hline Giant Eagle Owl & - & C & - & - & - & - & - & C & - & - & $C$ & - & - & - \\
\hline White-faced Scops Owl & $C$ & - & - & $C$ & - & - & - & - & - & - & - & - & - & - \\
\hline Spotted Eagle Owl & $C$ & - & - & - & - & - & - & - & - & - & - & - & - & - \\
\hline Barred Owlet & - & - & - & - & C & - & - & - & - & - & - & - & - & - \\
\hline Bearded Woodpecker & - & - & - & - & - & - & $\mathrm{C}$ & - & - & - & - & $C$ & - & - \\
\hline Olive Woodpecker & - & - & - & - & - & C & & - & - & $C$ & - & - & - & - \\
\hline Cardinal Woodpecker & - & - & - & - & M & - & - & M & - & - & - & - & - & C \\
\hline Golden-tailed Woodpecker & $\mathrm{M}$ & - & - & - & - & - & - & - & - & - & - & - & - & - \\
\hline Bennett's Woodpecker & - & - & - & - & - & C & - & - & - & - & - & - & - & - \\
\hline Little-spotted Woodpecker & - & - & - & - & C & - & - & - & - & - & - & - & - & - \\
\hline Pale-billed Hornbill & - & - & - & - & - & - & - & C & - & - & - & - & - & - \\
\hline Crowned Hornbill & $C$ & - & - & $C$ & - & - & - & - & - & - & - & - & - & - \\
\hline Trumpeter Hornbill & - & - & - & - & C & - & - & - & - & - & - & - & - & - \\
\hline Arnot's Chat & $C$ & M & C & - & - & - & C & - & C & $\mathrm{M}$ & - & - & - & - \\
\hline Greater-striped Swallow & - & - & - & - & - & C & - & - & - & - & - & - & - & - \\
\hline Mosque Swallow & - & - & - & - & - & - & - & - & - & - & - & - & $C$ & - \\
\hline Red-breasted Swallow & - & - & C & - & - & $\mathrm{C}$ & - & - & - & - & - & - & - & - \\
\hline Lesser-striped Swallow & - & - & $\mathrm{C}$ & - & - & - & - & - & - & - & - & - & - & - \\
\hline European Swallow & - & - & - & - & - & - & $\mathrm{C}$ & - & - & - & - & - & - & - \\
\hline Meyer's Parrot & - & - & - & $C$ & - & - & - & - & - & - & $\mathrm{C}$ & - & - & - \\
\hline Half-collared Kingfisher & - & - & - & - & - & - & - & - & C & - & - & - & - & - \\
\hline Malachite Kingfisher & - & - & - & $\mathrm{C}$ & - & - & - & - & - & - & $C$ & - & - & - \\
\hline Brown-headed Kingfisher & - & - & - & $\mathrm{C}$ & - & - & - & - & - & - & - & - & - & - \\
\hline Striped Kingfisher & - & - & - & - & - & - & - & - & - & - & $\mathrm{C}$ & - & - & - \\
\hline European Roller & - & - & C & - & - & - & - & - & - & - & - & - & - & - \\
\hline Lilac-breasted Roller & - & - & - & - & - & C & - & - & - & - & - & - & - & - \\
\hline Broad-billed Roller & - & - & - & - & - & - & - & - & - & - & - & $C$ & - & - \\
\hline Red-billed Wood hoopoe & - & - & - & - & - & - & - & - & - & - & - & $C$ & - & - \\
\hline Hoopoe & - & - & - & - & - & - & - & - & - & - & - & $C$ & - & - \\
\hline Black-backed Barbet & - & - & - & - & - & - & - & - & $\mathrm{C}$ & - & - & - & - & - \\
\hline Black-collared Barbet & - & - & - & - & - & - & - & - & - & $C$ & - & - & - & - \\
\hline Miombo pied Barbet & - & C & - & - & C & - & - & C & - & - & - & - & - & - \\
\hline Whyte's Barbet & - & C & - & - & - & - & - & - & - & - & - & - & - & - \\
\hline Violet-backed Starling & - & - & - & - & - & - & - & - & - & - & - & - & $C$ & C \\
\hline Sharp-tailed Starling & - & - & - & - & - & - & - & - & $\mathrm{C}$ & - & $\mathrm{C}$ & - & - & $\mathrm{C}$ \\
\hline
\end{tabular}

1, Parinari curatellifolia; 2, Brachystegia boehmii; 3, Lannea discolour; 4, Brachystegia spiciformis; 5, Julbernadia paniculata; 6, Vitex doniana; 7, Albizia anthunesia; 8, Pterocarpus angolensis; 9 , Uapaca kirkiana; 10, Anisophyllea boehmii; 11, Isoberlinia angolensis; 12, Diplorhynchus condylocarpon; 13, Bridelia micrantha and 14, Hymonecardia acidia.

M, Mwekera; C, Chimfushi.

provisioning functions and services. However, attempts to implement the Forest Policy of 1998 in Zambia face challenges as the legal aspects of forest resource management are still under the Forest Act of 1973, despite having the Forest Act of 1999 formulated. The old Forest Policy and Forest Act in use do not suit the changing environment, making understanding and appreciation by multiple stakeholders of the role of natural resources difficult.

Anthropogenic activities such as the lighting of fires, collection of dead wood, and land clearing affect the existence of forested lands, thereby threatening the persistence of cavity-nesting birds (Lee \& Irwin 2005; Newton 1998). For instance, small patches of woodlands isolated by human activities are avoided by the cavitynesting birds even if they contain suitable nest sites (Loman 2006). Therefore, steps are needed from multiple stakeholders, including wildlife managers, policy makers and local communities to ensure the preservation of bird diversity and retention of ecological processes such as nesting, breeding, feeding and roosting. Such steps will help local communities derive benefits from ecosystem services such as ecotourism, which depends on birds and other wildlife species (Snyman 2012). Further, for cavity-nesting bird restoration programmes, there is need to explore and investigate effectiveness of use of artificial nest sites (Wilson \& Hockey 2013) and rehabilitation of disturbed woodlands (Benayas \& Bullock 2012; Gomez 2014). 


\section{Conclusion}

The survival prospects of cavity-nesting birds are greatly influenced by the extent of human disturbance of woodlands. The negative effects of disturbance of woodlands may result in the local extinction of certain bird species and significant impacts on the structure and behaviour of bird communities. Additional research is required to investigate further the impacts of human activities on bird species, particularly of other species groupings, and also the impacts of climate change on the distribution and abundance of birds.

The abundance and diversity of wood in miombo systems influence the availability of tree cavities to primary and secondary cavity-nesting birds. Human impacts that reduce abundance and diversity of wood have a negative bearing on cavity-nesting birds. However, these species can be effectively protected by increasing forest protection through sound policies and sustainable land use practices, awareness creation and provision of sustainable livelihoods to rural populations.

\section{Acknowledgements}

We thank the Copperbelt University, management and authorities of the Mwekera National Forests No. 6 and the Chimfushi Wildlife Orphanage for facilitating this research.

\section{Competing interests}

The authors declare that they have no financial relationships which may have inappropriately influenced them in writing this article.

\section{Authors' contributions}

V.R.N was team leader, made experimental and project design and wrote the manuscript, F.C.C, E.C-K. and P.A.L. participated in project design and execution.

\section{References}

Avery, T.E. \& Burkhart, H.E., 1994, Forest measurements, 4th edn., McGraw-Hill Inc., New York.

Barry, J., Birchenough, S., Norris, B. \& Ware, S., 2013, 'On the use of sample indices to reflect changes in benthic fauna biodiversity', Ecological Indicators 26, 154-162. http://dx.doi.org/10.1016/j.ecolind.2012.11.004

Belthoff, J.R. \& Ritchison, G., 1990, 'Nest-site selection by Eastern screech owls in Central Kentucky', Condor 92, 982-990. http://dx.doi.org/10.2307/1368734

Benayas, J.M.R. \& Bullock, J.M., 2012, 'Restoration of biodiversity and ecosystem services on agricultural land', Ecosystems 15, 883-899. http://dx.doi.org/10.1007/ s10021-012-9552-0

Carlson, A., Sandström, U. \& Olsson, O., 1998, 'Availability and use of natural tree holes by cavity nesting birds in a Swedish deciduous forest', Ardea 86, 109-119.

Carpenter, S.R. \& Brock, W.A., 2008, 'Adaptive capacity and traps', Ecology and Society 13, 40, viewed 03 January 2015, from: http://www.ecologyandsociety.org/vol13/ iss2/art40/

Carrete, M., Lambertucci, S.A., Speziale, K., Ceballos, O., Travaini, A., Delibes, M. et al., 2010, 'Winners and losers in human-made habitats: Interspecific competition outcomes in two Neotropical vultures', Animal Conservation 13, 390-398. http:// dx.doi.org/10.1111/j.1469-1795.2010.00352.x

Central Statistical Office (CSO), 2012, Zambia 2010 census of population and housing Central Statistical Office, Lusaka.

Cockle, K.L., Martin, K. \& Wesolowski, T., 2011, 'Woodpecker, decay, and the future of cavity-nesting vertebrate communities worldwide', Frontiers in Ecology and the Environment 9(7), 377-382. http://dx.doi.org/10.1890/110013

Czeszczewik, D. \& Walankiewicz, W., 2003, 'Natural nest sites of the Pied Flycatcher Ficedula hypoleuca in a primeval forest', Ardea 91, 221-230.
Dewees, P., Campbell, B., Katerere, Y., Sitoe, A., Cunningham, A.B., Angelsen, A. et al., 2011, Managing the miombo woodlands of Southern Africa: Policies, incentives, and options for the rural poor, Program on Forests, Washington, DC.

Dobkin, D.S., Rich, A.C., Pretare, J.A. \& Pyle, W.H., 1995, 'Nest-site relationships among cavity-nesting birds of riparian and snowpocket aspen woodlands in the northwestern Great Basin', Condor 97, 694-707. http://dx.doi.org/10.2307/ 1369178

dos Anjos, L., 2006, 'Bird species sensitivity in a fragmented landscape of the Atlantic forest in Southern Brazil', Biotropica 38, 229-234. http://dx.doi.org/10.1111/ j.1744-7429.2006.00122.x

Dowsett, R.J., Aspinwall, D.R. \& Dowsett-Lemaire, F., 2008, The birds of Zambia, Tauraco Press, Liège.

Du Plessis, M.A., 1992, 'Obligate cavity-roosting as a constraint on dispersal of green (red-billed) woodhoopoes: Consequences for philopatry and the likelihood of inbreeding', Oecologia 90, 205-211. http://dx.doi.org/10.1007/BF00317177

Du Plessis, M.A., 1995, 'The effects of fuel wood removal on the diversity of some cavity-using birds and mammals in South Africa', Biological Conservation 74(2), 77-82. http://dx.doi.org/10.1016/0006-3207(95)00016-W

Du Plessis, M.A., Simmons, R.E. \& Radford, A.N., 2007, 'Behavioural ecology of the Namibian Violet Woodhoopoe Phoeniculus damarensis', Ostrich 78(1), 1-5. $\mathrm{http}: / / \mathrm{dx}$.doi.org/10.2989/OSTRICH.2007.78.1.1.45

Eriksen, C., 2007, 'Why do they burn the 'bush'? Fire, rural livelihoods, and conservation in Zambia', Geographical Journal 173(3), 242-256. http://dx.doi. org/10.1111/j.1475-4959.2007.00239.x

Farris, K.L., Huss, M.J. \& Zack, S., 2004, 'The role of foraging woodpeckers in the decomposition of ponderosa pine snags', Condor 106, 50-59. http://dx.doi. org/10.1650/7484

Fisher, R.J. \& Wiebe, K.L., 2005, 'Nest site attributes and temporal patterns of Northern flicker nest loss: Effects of predation and competition', Oecologia 147, 744-753. http://dx.doi.org/10.1007/s00442-005-0310-2

Folke, C., Carpenter, S.R., Walker, B., Scheffer, M., Chapin, T. \& Rockstrom, J., 2010. 'Resilience thinking: Integrating resilience, adaptability and transformability', Ecology and Society 15, 20, viewed 21 December 2014, from http://www. ccologyandsocicty.org/voll5! iss4/art20/

Fowler, J., Cohen, L. \& Jarvis, P., 2006, Practical statistics for field biology, 2nd edn., John Willey and sons, West Sussex, England.

Frost, P., 1996, 'The ecology of miombo woodlands', in B. Campbell (ed.), The miombo in transition: Woodlands and welfare in Africa, pp. 11-57, Centre for International Forestry Research, Bogor.

Gibbons, P., Lindenmayer, D.B., Barry, S.C. \& Tanton, M.T., 2002, 'Hollow selection by vertebrate fauna in forests of southeastern Australia and implications for forest management', Biological Conservation 103, 1-12. http://dx.doi.org/10.1016/ S0006-3207(01)00109-4

Gomez, E.D., 2014, 'Effects of tree retention on cavity-nesting birds in northern Sweden', M.Sc. thesis, Sweden University of Agricultural Sciences, Umea.

Harrington, L.A., Harrington, A.L., Yamaguchi, N., Thom, M.D., Ferreras, P., Windham, T.R. et al., 2009, 'The impact of native competitors on an alien invasive: Temporal niche shifts to avoid interspecific aggression', Ecology 90, 1207-1216. http://dx. doi.org/10.1890/08-0302.1

Hockey, P.A.R., Dean, W.R.J. \& Ryan, P.G. (eds.), 2005, Robert's birds of Southern Africa, 7th edn., John Voelcker Bird Book Fund, Cape Town.

Holt, E.A. \& Miller, S.W., 2011, 'Bio-indicators: Using organisms to measure environmental impacts', Nature Education Knowledge 2, 1-10.

Hunter, J.E. \& Mazurek, M.J., 2003, 'Characteristics of trees used by nesting and roosting Vaux's Swifts in northwestern California', Western Birds 34, 225-229.

Jackson, J.A. \& Jackson, B.J.S., 2004, 'Ecological relationships between fungi and woodpecker cavity sites', Condor 106(1), 37-49. http://dx.doi.org/10.1650/7483

Jones, L., Jaspars, S., Pavanello, S., Ludi, E., Slater, R., Arnall, A. et al., 2010, 'Responding to a changing climate: Exploring how disaster risk reduction, social protection and livelihoods approaches promote features of adaptive capacity', Working Paper livelihoods approaches promote features of adaptive capacity', Working Paper
319, Overseas Development Institute, London, viewed 09 November 2014, from 319, Overseas Development Institute, London, view
http://www.odi.uk/resources/download/4790.pdf

Jost, L., 2006, 'Entropy and diversity', Oikos 113, 363-375. http://dx.doi.org/10.1111/ j.2006.0030-1299.14714.x

Joy, J.B., 2010, 'Characteristics of nest cavities and nest trees of red-breasted sapsuckers in coastal montane forests', Journal of Field Ornithology 71, 525-530. http://dx.doi.org/10.1648/0273-8570-71.3.525

Kalaba, F.K., Quinn, C.H. \& Dougill, J.A., 2013, 'The role of forest provisioning ecosystem services in coping with household stresses and shocks in miombo woodlands, Zambia', Ecosystem Services 5, 143-148. http://dx.doi.org/10.1016/j. ecoser.2013.07.008

Kappes, J.J. \& Davis, J.M., 2008, 'Evidence of positive indirect effects within a community of cavity-nesting vertebrates', Condor 110, 441-449. http://dx.doi. org/10.1525/cond.2008.8472

Kemp, A.C., 2000, 'Southern ground hornbill', in K.N. Barnes (ed.), The Eskom red data book of birds of South Africa, Lesotho and Swaziland, pp. 117-119, Birdlife South Africa, Johannesburg.

Kemp, A.C., 2001, 'Family Bucerotidae (hornbills)', in J. Del Hoyo, A. Elliott, \& J. Sargatal (eds.), Handbook of birds of the World, Volume 6: Mousebirds to hornbills, pp. 436-526, Lynx Editions, Barcelona.

Koenig, W.D., 2003, 'European Starlings and their effect on native cavity-nesting birds', Conservation Biology 17, 1134-1140. http://dx.doi.org/10.1046/j.1523-1739. 2003.02262.x 
Krauss, K.W., Keeland, B.D., Allen, J.A., Ewel, K.C. \& Johnson, D.J., 2007, 'Effects of season, rainfall and hydrogeomorphic setting on mangrove tree growth in Micronesia', Biotropica 39, 161-170. http://dx.doi.org/10.1111/j.1744-7429. 2006.00259.x

Laudenslayer, Jr. W.F., 2002, 'Cavity-nesting bird use of snags in eastside pine forests of northeastern California', in W.F. Laudenslayer Jr., P.J. Shea, B.V. Valentine, C.P. Weatherspoon, and T.E. Lisle (eds.), Proceedings of the Symposium on the Ecology and Management of Dead Wood in Western Forests, pp. 223-236, Pacific and Management of Dead Wood in Western Forests, pp. $223-23$
Southwest Forest and Range Experimentation Station, Berkeley, CA.

Lee, D.C. \& Irwin, L.L., 2005, 'Assessing risks to spotted owls from forest thinning in fire-adapted forests of the western United States', Forest Ecology and Management 211, 191-209. http://dx.doi.org/10.1016/j.foreco.2005.02.001

Lehmkuhl, J.F., Everett, R.L., Schellhaas, R., Ohlson, P., Keenum, D., Riesterer, H. et al., 2003, 'Cavities in snags along a wildfire chronosequence in eastern Washington', Journal of Wildlife Management 67, 219-228. http://dx.doi.org/10.2307/3803077

Leverett, R.T., 2010, 'Measuring tree height by tape and clinometers scenarios', Bulletin of Eastern Native Tree Society 5(3\&4), 3-12.

Loman, J., 2006, 'Does nest site availability limit the density of hole nesting birds in small woodland patches?', Web Ecology 6, 37-43. http://dx.doi.org/10.5194/we-6-37-2006

Magurran, A.E., 2004, Measuring biological diversity, Blackwell Scientific Press, Oxford.

Martin, K. \& Eadie, M.J., 1999, 'Nest webs: A community-wide approach to the management and conservation of cavity-nesting forest birds', Forest Ecology and Management 115, 243-257. http://dx.doi.org/10.1016/S0378-1127(98)00403-4

Mayer, A.L., Donovan, R.P. \& Pawlowski, C.W., 2014, 'Information and entropy theory for the sustainability of coupled human and natural systems', Ecology and Society, 19 11, viewed 23 February 2015, from http://dx.doi.org/10.5751/ES-06626-190311

Mcgill, B.J., Etienne, R.S., Gray, J.S., Alonso, D., Anderson, M.J., Benecha, H.K., et al., 2007, 'Species abundance distributions: Moving beyond single prediction theories to integration within an ecological framework', Ecology Letters 10, 995-1015. http://dx.doi.org/10.1111/j.1461-0248.2007.01094.x

Meyer, S., 2008, The barn owl as a control agent for rat populations in semi-urban, University of Witwatersrand, Johannesburg.

Millington, A.C., Chritchley, R.W., Douglas, T.D. \& Ryan, P., 1994, 'Prioritization of indigenous fruit tree species based on farmers evaluation criteria: Some preliminary results from central region, Malawi', in Proceedings of the Regional preliminary results from central region, Malawi', in Proceedings of the Regional
Conference on Indigenous Fruit Trees of the Miombo Ecozone of Southern Africa, Mangochi, Malawi, January 23-27, 1994, ICRAF, Nairobi, pp. 97-105.

Ministry Of Tourism, Environment and Natural Resources (MTENR) and United Nation's Food and Agricultural Organisation (FAO), 2008, Integrated land use assessment, 2005-2008. Forestry Department, MTENR, Lusaka and United assessment, 2005-200
Nation's FAO, Rome.

Minitab, 2004, Minitab, ver. 14, Minitab Inc., Pennsylvania.

Nelson, F., 2008, Integrative thinking for a changing planet, Maliasili Initiatives, Arusha.

Newman, K. \& Read, C., 2008, 'Birds', in V. Carruthers (ed.), The wildlife of Southern Africa: The larger illustrated guide to the animals and plants of the region, $\mathrm{pp}$ 114-163, Random House Struik, Cape Town.

Newton, I., 1998, Population limitation in birds, Academic press, Cambridge, MA

Ober, H.K. \& Minogue, P.J., 2007, Dead wood: Key to enhancing wildlife diversity in forests, Wildlife Ecology and Conservation, Gainesville, FL.

O'Brien, J.J., Oberbauer, S.F., Clark, D.B. \& Clark, D.A., 2008, 'Phenology and stem diameter increment seasonality in a Costa Rican wet tropical forest', Biotropica 40, 151-159. http://dx.doi.org/10.1111/j.1744-7429.2007.00354.x

Politi, N. \& Hunter, M. Jr., 2009, 'Nest selection by cavity-nesting birds in subtropical montane forests of Andes: Implications for sustainable forest management', Biotropica 41(3), 354-360. http://dx.doi.org/10.1111/j.1744-7429.2008.00481.x

Radford, A.N. \& Du Plessis, M.A., 2003, 'The importance of rainfall to a cavity-nesting species', lbis 145, 692-694. http://dx.doi.org/10.1046/j.1474-919X.2003.00198.x

Reed, J.M., 2001, 'Woodpeckers and allies', in C. Elphick, J.B. Dunning, Jr. \& D. Sibley (eds.), The Sibley guide to bird life and behaviour, pp. 380-1437, Christopher Helm, London.

Reid, J.L., Mendenhall, C.D., Rosales, J.A. Zahawi, R.A. \& Holl, K.D., 2014, 'Landscape context mediates avian habitat choice in tropical forest restoration', PLoS One 9(3), e90573, viewed 3 January 2015, from http://dx.doi.org/10.1371/journal. pone.0090573
Rhodes, B.K., O'Donnell, C.F.J. \& Jamieson, I.G., 2009, 'The role of predation, microclimate and cavity abundance in the evolution of New Zealand's tree-cavity nesting avifauna', Notornis 56, 190-200.

Richardson, C.T. \& Miller, C.K., 1997, 'Recommendations for protecting raptors from human disturbance: A review', Wildlife Society Bulletin 25, 634-638.

Roberts, D.L., 2007, 'Effects of tropical forest fragmentation on ecology and conservation of migrant and resident birds in lowland Costa Rica', PhD Thesis, University of Idaho, Moscow.

Ryan, C., Williams, M. \& Grace, J., 2010, 'Above and belowground carbon stocks in a miombo woodland landscape of Mozambique', Biotropica 43, 423-432. http:// dx.doi.org/10.1111/j.1744-7429.2010.00713.x

Saab, V.A., Dudley, J. \& Thompson, W.L., 2004, 'Factors influencing occupancy of nest cavities in recently burned forests', Condor 106, 20-36. http://dx.doi. org/10.1650/7485

Saab, V.A., Russell, R.E. \& Dudley, J.G., 2007, 'Nest densities of cavity-nesting birds in relation to postfire salvage logging and time since wildfire', Condor 109, 97-108. http://dx.doi.org/10.1650/0010-5422(2007)109[97:NDOCBI]2.0.CO;2

Schwartz, M.W., Caro, T.M. \& Banda-Sakala, T., 2002, 'Assessing the sustainability of harvest of $P$. angolensis in Rukwa region, Tanzania', Forest Ecology and Management 170, 259-269. http://dx.doi.org/10.1016/S0378-1127(01) Managemer

Shigo, A.L. \& Marx, H.G., 1977, Compartmentalization of decay in trees, USDA Forest Service Agriculture Information Bulletin 405, Washington, DC.

Sinclair, A.R.E., Fryxell, J.M. \& Caughley, G., 2006, Wildlife ecology, conservation and management, 2nd edn., Blackwell Publishing, Malden, MA.

Snyman, S., 2012, 'The role of ecotourism employment in poverty reduction and community perceptions of conservation and tourism in Southern Africa', Journal of Sustainable Tourism 20, 395-416. http://dx.doi.org/10.1080/09669582.2012.6 57202

Stephens, S.L., 2004, 'Fuel loads, snag abundance, and snag recruitment in an unmanaged Jeffrey pine-mixed conifer forest in Northwestern Mexico', Forest Ecology and Management 199, 103-113. http://dx.doi.org/10.1016/j. foreco.2004.04.017

Stringer, L., Mngoli, M., Dougill, A., Mkwambisi, D., Dyer, J. \& Kalaba, F., 2012 'Challenges and opportunities for carbon management in Malawi and Zambia', Carbon Management 3, 159-173. http://dx.doi.org/10.4155/cmt.12.14

Trzcinski, M.K., Fahrig, L. \& Merriam, G., 1999, 'Independent effects of forest cover and fragmentation on the distribution of forest breeding birds', Ecological Applications 9, 586-593. http://dx.doi.org/10.1890/1051-0761(1999)009[0586:IE OFCA]2.0.CO;2

Tuomisto, H., 2012, 'An updated consumer's guide to evenness and related indices', Oikos 121, 1203-1218. http://dx.doi.org/10.1111/j.1600-0706.2011.19897.x

Turner II, B.L., Lambin, E.F \& Reenberg, A., 2007, 'The emergence of land change science for global environmental change and sustainability', Proceedings of the National Academy of Sciences 104, 20666-20671. http://dx.doi.org/10.1073/ pnas.0704119104

Walker, B. \& Salt, D., 2006, Resilience thinking: Sustaining ecosystems and people in a changing world, Island Press, Washington, DC.

Wesolowski, T., 1989, 'Nest-sites of hole-nesters in a primaeval temperate forest (Bialowieza National Park, Poland)', Acta Ornithologica 25, 321-351.

Wesolowski, T., 2002, 'Anti-predator adaptations in nesting Marsh Tits Parus palustris: The role of nest-site security', Ibis 144, 593-601. http://dx.doi. org/10.1046/j.1474-919X.2002.00087.x

Wilson, G. \& Hockey, P.A.R., 2013, 'Causes of variable reproductive performance by southern ground hornbill Bucorvus leadbeateri and implications for management', Ibis 155, 476-484. http://dx.doi.org/10.1111/ibi.12042

Wilson, P.R., Karl, B.J., Toft, R.J., Beggs, J.R. \& Taylor, R.H., 1998, 'The role of introduced predators and competitors in the decline of Kaka (Nestor meridionalis) populations in New Zealand', Biological Conservation 83, 175-185. http://dx.doi.org/10.1016/ S0006-3207(97)00055-4

Zimba, S.C., 2007, The fate of forest reserves in Zambia, a case study of Mwekera national forest No. 6, Mission Press, Ndola.

Zurlini, G., Petrosillo, I., Bruce-Jones, K. \& Zaccarelli, N., 2013, 'Highlighting order and disorder in social-ecological landscapes to foster adaptive capacity and sustainability', Landscape Ecology 28, 1161-1173. http://dx.doi.org/10.1007/ s10980-012-9763-y 